\title{
Cholesterol-Lowering Effects of Extract from Garcinia daedalanthera in Hyperlipidemic Rats
}

\author{
Sarah Zielda Najib ${ }^{1}$, Wilzar Fachri ${ }^{2}$, Rani Sauriasari ${ }^{1 *}$, Berna Elya ${ }^{1}$, Raymond Tjandrawinata ${ }^{3}$
}

\section{Sarah Zielda Najib' Wilzar Fachri ${ }^{2}$ Rani Sauriasari ${ }^{*}$ Berna Elya ${ }^{1}$ Raymond Tjandrawinata ${ }^{3}$ \\ ${ }^{1}$ Faculty of Pharmacy, University of Indonesia, Depok, INDONESIA. ${ }^{2}$ Faculty of Medicine, University of Indo- nesia, Salemba, INDONESIA. ${ }^{3}$ Dexa Laboratories of Biomolecular Sciences, Cikarang, INDONESIA.}

\section{Correspondence:}

Mrs. Rani Sauriasari Faculty of Pharmacy, University of Indonesia, Depok, INDONESIA.

Phone no : +62217270031

E-mail : rani@farmasi.ui.ac.id

\section{History}

- Submission Date: 05-04-2018;

- Review completed: 23-05-2018;

- Accepted Date: 30-07-2018.

DOI : 10.5530/pj.2018.6.191

Article Available online http://www.phcogj.com/v10/i6

\section{Copyright}

(C) 2018 Phcog.Net This is an open-access article distributed under the terms of the Creative Commons Attribution 4.0 International license.

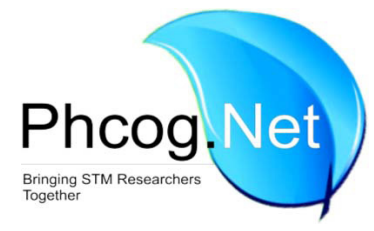

\begin{abstract}
Background: A native plant from Indonesia, Garcinia daedalanthera has been scientifically proven have antidiabetic effects and antioxidant activity. We hypothesized that Garcinia daedalanthera can modulate the lipid profiles of hyperlipidemic rats. Objective: This study aimed to evaluate the antihyperlipidemic potential of Garcinia daedalanthera extract. Materials and Methods: Garcinia daedalanthera leaves extract (GDE) were orally administrated to high fat diet-induced rats for 15 days. After the end of experimental period (43 days) the lipid profiles were estimated along with histopathological liver examination of animals. Results: The results showed that Garcinia daedalanthera extract significantly reduced the level of serum total cholesterol, total triglycerides and low-density lipoprotein as compared to control group with an increasing level of serum high-density lipoprotein. Furthermore, the extract has a favorable effect on histopathological study. Conclusion: This study proved antilipidemic property by lowering altered levels of lipid profile in male wistar rats and suggest lipid lowering effects of Garcinia daedalanthera extract which serves as a new potential natural product for preventing hyperlipidemia.
\end{abstract}

Key words: Anti-cholesterol, Garcinia, in vivo, Herbal, Pre-clinical study, Rat.

\section{INTRODUCTION}

Cholesterol plays a major role in human heart health, and is needed in the body to insulate nerves, make cell membranes and produce certain hormones, and it is an important lipid in some membranes. ${ }^{1}$ According to latest World Health Organization (WHO) report, about $50 \%$ of the heart attacks occur in individual with high level of cholesterol. ${ }^{2}$ High level of cholesterol or hypercholesterolemia gives high risks for the progression of Cardiovascular Diseases (CVDs). ${ }^{3}$ Cholesterol is positively associated with ischaemic stroke, has been observed to be inversely associated with a number of other outcomes such as cancer and chronic respiratory disease. ${ }^{4}$ Currently, hyperlipidemia has been treated with hydroxymethylglutarate glutarate coenzyme A (HMG-CoA) reductase inhibitors (statins), bile acid sequestrants, acyl-CoA cholesterol acyltransferase2 (ACAT2), inhibitors (ezetimibe), fibric acid derivatives (fibrates) and niacin in clinical practice (Toth, 2010). Clinical trials have also suggested a reduction in the incidence of ischemic heart disease by lowering serum cholesterol levels. ${ }^{5}$ Because many synthetic chemical drugs show side effects, there is an increasing public interest in natural medicines. Garcinia daedalanthera contains high level of phenolic and flavonoids compounds. ${ }^{6}$ The therapeutic properties of Garcinia daedalanthera have studied recently. ${ }^{7}$ This study was aim to study antihyperlipidemic activity of ethanolic extracts of Garcinia daedalanthera, in vivo.

Elevated levels of blood lipids are well documented as risk factors for cardiovascular disease. ${ }^{8}$ In hyperlipidemia, additional cholesterol is transferred from plasma to erythrocyte membranes. Therefore, erythrocytes received great attention as a cardiovascular risk factor (Tziakas et al., 2010). Particularly in hypercholesterolemia, cholesterol loading into erythrocyte membranes is increased; this resulted in activation of ROS production (Van Zwieten et al. 2012). Increases in ROS can lead to an imbalance of the cellular oxidation state, disrupting the redox balance such as the development of insulin resistance, $\beta$-cell dysfunction, impaired glucose tolerance, and mitochondrial dysfunction. ${ }^{9}$ It is a common perception that medicinal or edible plants that are rich in phenolics and flavonoids will benefit in giving protection towards excessive reactive oxygen species (ROS) and other oxidative stress-caused diseases such as inflammation and atherosclerosis. ${ }^{10}$ Garcinia daedalanthera contains high level of phenolic and flavonoids compounds. ${ }^{6,7}$ This study was aim to study antihyperlipidemic activity of ethanolic extracts of Garcinia daedalanthera, in vivo. 


\section{MATERIALS AND METHODS}

\section{Preparation of Material}

The fresh leaves of Garcinia daedalanthera were collected and determined by Bogor Botanical Garden, Indonesia. Garcinia daedalanthera was extracted with ethanol 80\%. Sucrose (Sigma Aldrich), HFD (High Fat Diet) (IPB), Ketamine (KEPRO), Xylazine (Interchemie), Glucose (Sigma Aldrich), Pentobarbital sodium (AST Farma).

\section{Preparation of Animals}

Eight-week old male Wistar rats were purchased from Indoanilab, Bogor. The rats were acclimated for two weeks before use. The animals were cared for according to approve procedure by IACUC (Institutional Animal Care and Use Committee). The animal study was conducted with approval from the ethical institutional advisory committee as suggested by the Association for Assessment and Accreditation of Laboratory Animal Care (AAALAC). Twenty-four male rats were divided into six groups of four animals each. Group 1 was considered as normal control, which received purified water solution. Group 2 was considered as diabetic control, which administered HFD+ sucrose 30\%. Group 3 was considered as diabetic positive control, which received HFD+ sucrose $30 \%$ and acarbose $(20 \mathrm{mg} / \mathrm{kgBB})$. Group 4 was considered as treatment group which received HFD + sucrose 30\% and Garcinia daedalanthera (GDE) extract $1 \mathrm{mg} / \mathrm{kgBB}$. Group 5 was considered as treatment group which received HFD + sucrose $30 \%$ and Garcinia daedalanthera (GDE) extract $10 \mathrm{mg} / \mathrm{kgBB}$. Group 6 was considered as treatment group which received HFD + sucrose 30\% and Garcinia daedalanthera (GDE) extract $100 \mathrm{mg} / \mathrm{kgBB}$. High Fat Diets were purchased from School of Animal Husbandry, IPB. The treatment group was given HFD and sucrose 30\% through drinking water for 45 days. High fat diet contains $30 \%$ corn, $30 \%$ corn gluten meal, and $25 \%$ beef tallow.

\section{Lipid Profile Determination}

The serum was measured using commercial kits from ELITechGroup (France) for lipid analysis on day $1^{\text {st }}, 28^{\text {th }}$, and $43^{\text {rd }}$ of period treatment. The last day of treatment, the animals were anesthetized after an overnight fast (16h). The animals underwent cardiac puncture to collect blood. Afterwards, the vials were centrifuged at $300 \times \mathrm{g}$ for 10 min and the resultant serum was used for further analysis of TG, TC, HDL-C(High Density Lipoprotein-Cholesterol), and LDL-C (Low Density Lipoprotein-Ccholesterol). Serum lipid levels were colorimetrically measured by routine procedures. All analyzes were performed according to the manufacturer's instructions in triplicate.

\section{Statistical Analysis}

The results were expressed as mean \pm SEM of six rats per group and statistical significance was evaluated by one-way analysis of variance (ANOVA) using SPSS (version 22) program followed by LSD. Values were considered statistically significant when $P<0.05$.

\section{RESULTS AND DISCUSSION}

HFD and sucrose $30 \%$ was given during the 43 days of treatment period in order to increase cholesterol levels in the treatment groups. 2 weeks after acclimatization, serum is taken from the tail (D0) as baseline before being given HFD and sucrose. On day $28^{\text {th }}$, serum was taken to ensure the success of induction HFD and sucrose and the last day of treatment, serum was taken to see the effect of Garcinia daedalanthera extract on the decrease of lipid profile. There was a significant difference between the normal group and the treatment group on day 28 . In the normal group there was no significant in cholesterol levels but in the diabetes control group, there was an increase in cholesterol levels. This proves that feeding HFD affects cholesterol levels of rats.

Figure 1 shown that all groups had elevated cholesterol levels on day 28 except the blank group which only received purified water during the treatment period. On day 43 , in spite of the continuous given HFD, the extract was able to reduce level of cholesterol significantly at doses 10 and $100 \mathrm{mg} / \mathrm{Kg} \mathrm{BW}$, but not at dose $1 \mathrm{mg} / \mathrm{Kg}$ BW. Regular administrations of Garcinia daedalanthera modified the disorders of serum lipid metanolism, Garcinia daedalanthera consistenly normalized serum TC concentration in 2 weeks which appear below to acarbose. Garcinia daedalanthera was extracted using ethanol that means extract of Garcinia daedalanthera included in polar extract. The polar extract is the key enzymes in the process of cholesterol synthesis and metabolism. The polar extract could enhance the activity and mRNA expression level of CYP7A1 by promoting the cholesterol excretion of bile acid as its metabolite; meanwhile it inhibited the activity and mRNA expression level of HMG-CoA reductase to depress the cholesterol biosynthesis. ${ }^{11}$ The hypercholesterolemia is considered to be the most prevalent positive risk factor for initiation of atherosclerosis and coronary heart disease (Lewis, 2011). Garcinia daedalanthera has high level of polyphenols. ${ }^{6}$ Polyphenols such as flavonoids, which possess antioxidative activity that suggested to have a preventive effect for arteriosclerosis (Mojzisova and Kuchta, 2001). The extract of this plant was standardized according to Farmakope Herbal Indonesia in order to get reproducible product and to provide the predictable efficacy.

Long-term acarbose treatment significantly improved triglyceride levels. ${ }^{12}$ But in this study, group that was given acarbose treatment does not improved triglyceride levels (Figure 2). On day 43, the treatment group at dose of $1 \mathrm{mg} / \mathrm{Kg}$ BW increased triglyceride levels which means administration Garcinia daedalanthera at dose $1 \mathrm{mg} / \mathrm{kgBW}$ does not affect triglyceride levels but treatment group at doses 10 and $100 \mathrm{mg} /$ Kg BW decreased triglyceride levels. It is suspected that there are some compounds appear at doses of 10 and $100 \mathrm{mg} / \mathrm{Kg}$ BW which affects on triglyceride levels. The concentration of Garcinia daedalanthera is responsible for majority of pharmacological effects. Polyphenols can act as HMG-CoA reductase inhibitors, thus by mimicking statins action, polyphenols could covalently linked to sugar residue so HMG-CoA reductase cannot hydrolase R-linked HMG which competes with the S-linked substrate for catalytic pocket of the enzyme then cannot be mevalonate, which is a precursor of later steps in cholesterol synthesis. ${ }^{13}$ Some polyphenols, such as naringenin and hesperidin are identical to S-linked 3-hydroxy-3-methyl-glutaryl residue of HMG-CoA, a substrate of HMG-CoA reductase. AMPK activation is also a molecular target of many natural polyphenols, and AMPK may be responsible for therapeutic effects of polyphenols against various metabolic disorders, including obesity, diabetes, hyperlipidemia and nonalcoholic fatty liver disease. ${ }^{13}$ Flavonoids could be cyclic nucleotide phosphodiesterases (PDEs), PDEs catalyze hydrolysis of cAMP (cyclic adenosine monophosphate) and The rate of triglyceride (TG) hydrolysis (lipolysis) is positively regulated by increase in intracellular cAMP. cAMP activates, a cAMP dependent protein kinase, PKA which stimulates hormone-sensitive lipase (HSL), one of the key molecules controlling lipolysis, by promoting its phosphorylation. flavonoids can induce lipolysis in adipose tissue, likely through inhibition of PDEs and antagonism of cAMP degradation that could make lowering triglyceride levels.

In Figure 3 shown that during D0 until D28 there was a decrease in HDL level in all treatment groups then 15 days later of administration GDE changes in HDL level, which group that was given $1 \mathrm{mg} / \mathrm{Kg} \mathrm{BW}$ increases HDL level but does not occur in group doses 10 and $100 \mathrm{mg} / \mathrm{Kg}$ BW. The diabetic control group there was a decrease in HDL levels on the $28^{\text {th }}$ day 


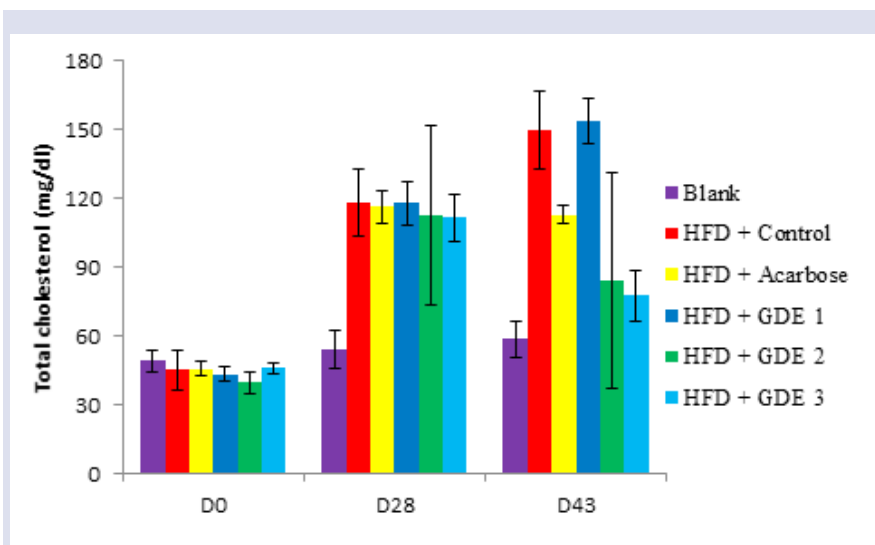

Figure 1: Effect of Garcinia daedalanthera extract on total cholesterol.

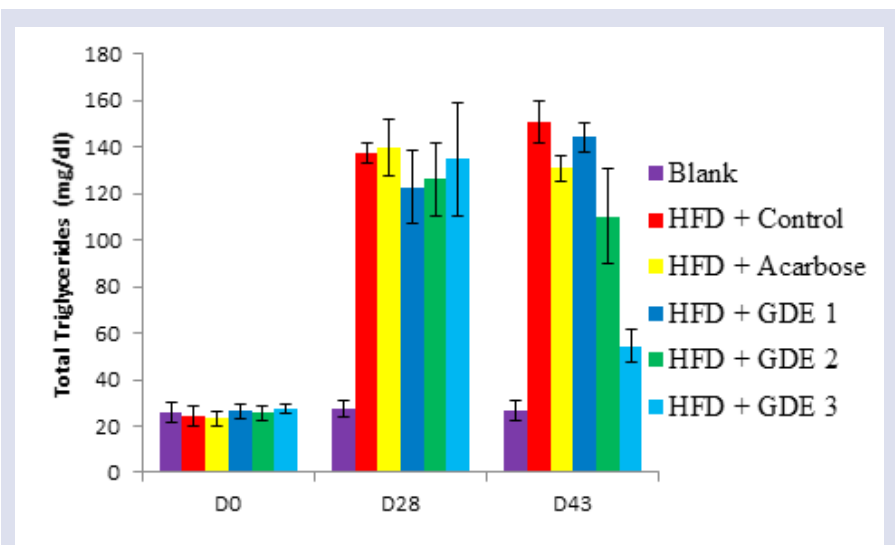

Figure 2: Effect of Garcinia daedalanthera extract on total triglycerides.

and the $43^{\text {rd }}$ day this was due to an interruption of lipid metabolism in diabetic rats. ${ }^{14}$

In the treatment group 3 there was decreased HDL levels until day 43 . But different thing shown in group 4 which given Garcinia daedalanthera extract dose $1 \mathrm{mg} / \mathrm{Kg} \mathrm{BW}$, after administration of Garcinia daedalanthera extract for 15 days there was an increase in HDL levels. In the treatment group which given Garcinia daedalanthera extract dose 10 and $100 \mathrm{mg} / \mathrm{KgBW}$ did not increase of HDL level, it is suspected that there is compound efficacious at dose $1 \mathrm{mg} / \mathrm{kg}$ Bw but covered activity when dose is raised. Because the sample is still in the form of extract so there are still many compounds contained in it.

Provision of Garcinia daedalanthera extract for 15 days proved to reduce LDL levels in Figure 4. In treatment group which given acarbose there was no decrease in LDL levels otherwise in treatment group given Garcinia daedalanthera extract there was a decrease in LDL levels. The highest decrease in LDL levels occurred at doses 10 and $100 \mathrm{mg} / \mathrm{Kg} \mathrm{BW}$. It is suspected that the compound that gives activity to the decrease of LDL level works at dosage above $10 \mathrm{mg} / \mathrm{Kg} \mathrm{BW}$.

Dietary supplementation of GDE significantly reduced serum TC, TG and LDL levels, suggesting that GDE has potential to be used as a natural health product to reduce atherosclerotic risk through a mechanism that is at least through lowering circulating cholesterol. The mechanism of anticholesterolemic has not observed yet. There was limited information on hyperlipidemic effect of Garcnia daedalanthera, to the best of

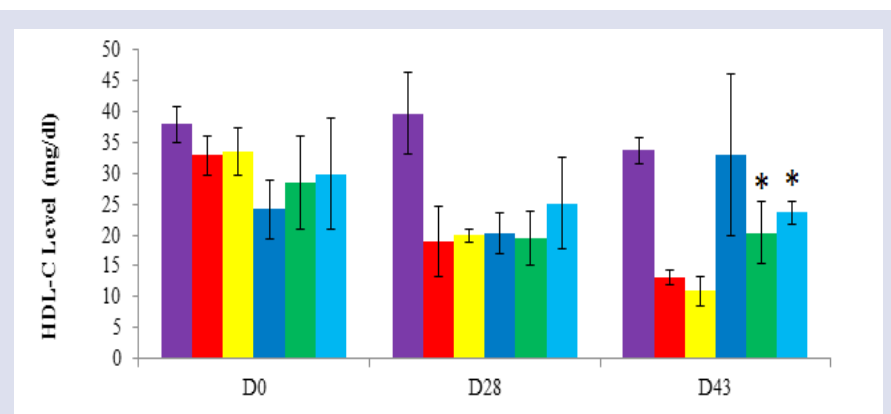

Figure 3: Effect of Garcinia daedalanthera extract on HDL-C level.

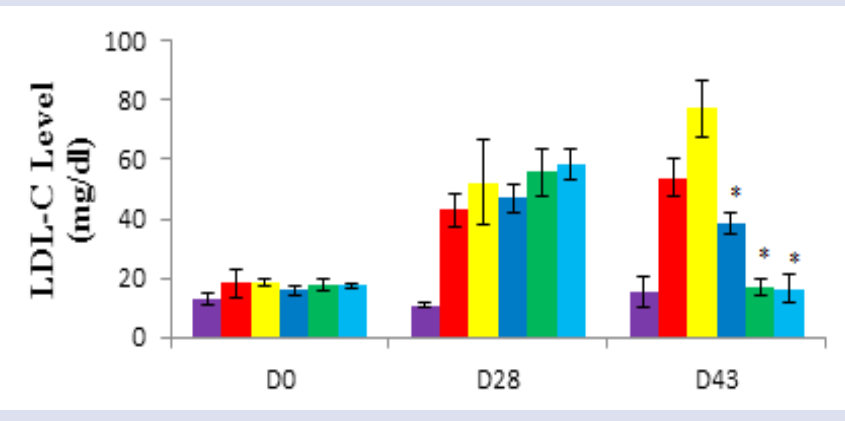

Figure 4: Effect of Garcinia daedalanthera extract on LDL-C level.

our knowledge, the current study reports for the first time the effect of Garcinia daedalanthera extract on blood lipid levels. It is suprising that GDE increased HDL levels at dose $1 \mathrm{mg} / \mathrm{kg}$ BW but decresed LDL level at doses 10 and $100 \mathrm{mg} / \mathrm{kgBW}$ in hiperlipidemic rats.

\section{CONCLUSION}

Garcinia daedalanthera extract was shown to have a lowering effect for total cholesterol, triglycerides, HDL-C and LDL-C of serum lipids in high-fat-diets. The lowering effect of Garcinia daedalanthera extract was shown to be caused by decreased in lipid profile.

\section{ACKNOWLEDGEMENT}

The author thanks to Hibah Pitta Grant UI for funding this research, also sincerely thanks to Laboratory of Pharmacognosy Faculty of Pharmacy Indonesia University and Laboratorium Animal Pharmacology, DLBS for providing facilities.

\section{CONFLICT OF INTEREST}

The authors have no conflict of interest to declare.

\section{REFERENCES}

1. Ma H. Cholesterol and Human Health. Nat Sci. 2004;2(4):17-21.

2. Thomas J, Shentu TP, Singh DK. Cholesterol?: Biosynthesis, Functional Diversity, Homeostasis and Regulation by Natural Products. In: Biochemistry. 2016.

3. Salvamani S, Gunasekaran B, Shaharuddin NA, Ahmad SA, Shukor MY. Antiartherosclerotic Effects of Plant Flavonoids. Biomed Res Int. 2014;2014:1-11.

4. Lawes CMM, Hoorn SV, Law MR, Rodgers A. High cholesterol. In: Comparative Quantification of Health Risks. 2003:391-496.

5. Region K. Relation of Body Mass Index with Lipid Profile and Blood Pressure in Healthy Females of Lower Socioeconomic Group. In J Dent Med Sci. 2013;10(1):19-21. 
6. Najib SZ, Ekayanti M, Ardiana L, Sauriasari R, Elya B. Pharmacognostical and Phytochemical Evaluation Leaves Ex- tract of Garcinia daedalanthera Pierre. J young Pharm. 2017;9(1):60-4. doi:10.5530/jyp.2017.

7. Kurniasari D. Isolasi dan Identifikasi Senyawa Antioksidan dan Penghambat Alpha Glucosidase dari Ekstrak Etil Asetat Daun Garcinia daedalanthera Pierre. thesis Uviersitas Indonesia. 2016.

8. H R, Nelson M. Hyperlipidemia as a Risk Factor for Cardiovascular Disease. Prim Care. 2013;40(1):195-211. doi:10.1016/j.pop.2012.11.003. Hyperlipidemia.

9. L J, Rains KS. Oxidative Stress, Insulin Signaling and Diabetes. Free Radic Bio Med. 2013;50(5):567-75. doi:10.1016/j.freeradbiomed.2010.12.006.OXIDATIVE.

10. Babu PVA, Liu D, Gilbert ER. Recent advances in understanding the anti-diabetic actions of dietary flavonoids. J Nutr Biochem. 2013;24(11):1777-89. doi:10.1016/j.jnutbio.2013.06.003.
11. Jiang C, Wang Q, WeiY, et al. Cholesterol-lowering effects and potential mechanisms of different polar extracts from Cyclocarya paliurus leave in hyperlipidemic mice. J Ethnopharmacol. 2015;176:17-26. doi:10.1016/j.jep.2015.10.006.

12. Hanefeld M, Cagatay M, Petrowitsch T, Neuser D, Petzinna D, Rupp M. Acarbose reduces the risk for myocardial infarction in type 2 diabetic patients?: metaanalysis of seven long-term studies. Eur Heart J. 2004;25(1):10-6. doi:10.1016/ S0195-668X(03)00468-8.

13. Janda E, Lascala A, Martino C, et al. PharmaNutrition Molecular mechanisms of lipid- and glucose-lowering activities of bergamot $\mathrm{fl}$ avonoids. Biochem Pharmacol. 2016;4:S8-S18. doi:10.1016/j.phanu.2016.05.001.

14. Wicaksono DWI. Pengaruh Ekstrak Buah Garcinia atroviridis Terhadap Kadar LDL pada Darah Tikus Wistar diberi Asupan Lemak Berlebih. 2013.

Cite this article: Sarah ZN, Wilzar F, Rani S, Berna E, Raymond T. Cholesterol-Lowering Effects of Extract from Garcinia daedalanthera in Hyperlipidemic Rats. Pharmacog J. 2018;10(6):1125-28. 